Proceedings

\title{
Measurements on the Greatest Trees of Hungary ${ }^{\dagger}$
}

\author{
Márton Takács ${ }^{1}$ and Ákos Malatinszky ${ }^{2, *}$
}

1 Department of Nature Conservation and Landscape Management, Hungarian University of Agriculture and Life Sciences, Páter K. 1, 2100 Gödöllő, Hungary; takacsmarton.msc@gmail.com

2 Department of Nature Conservation and Landscape Management, Hungarian University of Agriculture and Life Sciences, Páter K. 1, 2100 Gödöllő, Hungary; malatinszky.akos@uni-mate.hu

* Correspondence: malatinszky.akos@uni-mate.hu; Tel.: +36-30-566-3869

† Presented at the 1st International Electronic Conference on Biological Diversity, Ecology and Evolution, 1531 March 2021.

\begin{abstract}
Old trees with large girth are important habitats in various ecosystems, and function as cultural legacies as well. Our aims were to measure the greatest (considering girth) trees of Hungary, and compile their main data (including their health status and accessibility). We measured altogether 2000 trees in the area of 531 Hungarian settlements, belonging to 29 native and 43 non-native species. 1550 specimens belong to native species, while 450 are adventive. The most frequent among the greatest tree species is beech (Fagus sylvatica; 400 specimens) and the oak genus (Quercus spp.; 427 specimens). Most of them stand in a park or forest (not as a solitary tree), and live in the Northern Hungarian Mountain Range, while there is a low number of veteran trees in the Great Hungarian Plain. In terms of health status, at least three-quarters of the measured trees are in fair condition. From the registration in the nation-wide online database till our measurement (i.e., between 2000 and 2018) 121 great trees died, mostly due to natural causes (dehydration, storm damage). This number proves that any kind of documentation is important. More than half of the trees are easily accessible, while only about $9 \%$ is very difficult to reach. There is only a very limited case when a great tree receives legal protection at the local or national level even on its own or the habitat where it stands.
\end{abstract}

Keywords: tree girth; native; non-native; notable tree; veteran tree

Citation: Takács, M.; Malatinszky, Á. Measurements on the Greatest Trees of Hungary. Proceedings 2021, 68, x. https://doi.org/10.3390/xxxxx

Publisher's Note: MDPI stays neutral with regard to jurisdictional claims in published maps and institutional affiliations.

Copyright: (c) 2021 by the authors. Submitted for possible open access publication under the terms and conditions of the Creative Commons Attribution (CC BY) license (http://creativecommons.org/licenses/by/4.0/).

\section{Introduction}

Old and great trees contain several types of microhabitats, e.g., hollows, wood mould decaying wood in the crown, flaking bark which support specialised species including fungi, lichens, birds, small mammals etc. [1]. This is why the old and great trees are keystone structures in natural, agricultural and urban ecosystems [2]. Their great size and age provide ecological niches of value to specialised flora and fauna that cannot be provided by younger, smaller trees [3] and function as cultural-emotional legacies as well $[4,5]$. The preservation of landscapes, where there is still a high density of ancient trees, should be a priority for all European countries [6].

We believe that the greatest trees in Hungary represent extraordinary nature values and qualities in forests, cultural landscapes [7], as well as cultural heritage and landscape features. This is why we aimed to measure their general data (girth, perimeter, height etc.) and main infections (these results were published by [8]), the rate of different species among the greatest Hungarian trees, their health status, and accessibility. In Hungary, the first calls for the protection of ancient, giant trees date back to the early 20th century (e.g., [9]). The respect towards them has led to the protection of several ancient trees, most of them by the local governments [10]. Their main data are registered in online databases [11-13]. The greatest Hungarian database [11] started as a private website, but as a good example of citizen science, everyone can send new data; however, these will be uploaded 
only after validation (visited and measured on the spot) by the founder. Overviews on the cult of the oak genus and the presentation of some remarkable Hungarian oak trees were provided by [14], while in the case of lime species and sweet chestnut, see our previous articles [15,16].

As far as we know, there has been no similar research so far. Our study covers every Hungarian region, and 2000 very old, sizeable trees, some of them being champions with the largest species-specific girth or height in the country.

\section{Methods}

There is only one thorough online database that lists the greatest trees in Hungary, providing species, settlement, GPS coordinates, girth and year of its measurement [11]. 'Greatest' means great girth. Trees are listed in the database based on their smallest girth (perimeter) measured between 0 and $130 \mathrm{~cm}$ height. The minimum girth of each tree specimen to be listed in the database depends on the species, but usually, it is $600 \mathrm{~cm}$. Our original aim was to observe every specimen listed in this database. Their total number was 700 in 2008 when we started our study. Meanwhile, this number exceeded 3500 for 2020 and is still growing. This is why we present actual data of altogether 2000 trees that were listed in this database during our measurements between 2008 and 2017. Due to the high number of observed specimens, there were no repetitions.

We did not aim to measure the age of the trees (due to technical difficulties, risk of damage etc.). We made our measurements in the surroundings of altogether 531 Hungarian settlements. This can be considered as representative for the whole country.

The health status was presented on a 5-points scale $(1=$ dead, 2 = bad condition, $3=$ fair condition, 4 = good condition, 5 = excellent condition), based on the status of the crown, diseases, breaks, hollows and maintenance (Table 1). For example, if only a decayed trunk has remained without branches and bark, then this value is 1 . If there are pests or other organisms that cause damage or there is a hollow instead of the crown, but the tree is still able to grow new shoots (ie. is still vital), then this value is 3 . While in case of no pests or other organisms that would cause damage and healthy bark and crown without broken branches, this value is 5 .

Table 1. Health status categories for the measured trees.

\begin{tabular}{cl}
\hline Name of category & \multicolumn{1}{c}{ Description } \\
\hline $1=$ dead & $\begin{array}{l}\text { The tree dried out, fell, or was cut. Specimens that are still alive } \\
\text { but no longer reach the size necessary to be on the nation-wide } \\
\text { list belong to this category as well. }\end{array}$ \\
\hline $2=$ bad condition & $\begin{array}{l}\text { A few branches only, and/or severe infections. Usually, solitary } \\
\text { trees or beeches covered by several Polypores. }\end{array}$ \\
\hline $3=$ fair condition & $\begin{array}{l}\text { Half of the crown dried, bark injury (eg. old trees on wooded } \\
\text { pastures). Slight infections, unattended areas (eg. abandoned } \\
\text { castle parks). }\end{array}$ \\
\hline $5=$ good condition & $\begin{array}{l}\text { A few scars from brokes, some weeds. Trees of well-kept castle } \\
\text { parks, arboretums. }\end{array}$ \\
\hline $5=$ excellent condition & No infection, well-kept environments. \\
\hline
\end{tabular}

Accessibility was expressed by considering the quality (usability) of the road that leads to each specimen (eg., usable by car; or hard to follow even by foot), the presence or absence of informative signs both inside and outside the nearest settlements, distance from settlements or roads, densely surrounded by scrubs, etc. ( 1 = very difficult, 2 = poor, 3 = medium, 4 = good, 5 = excellent) (Table 2 ). 
Table 2. Accessibility categories for the measured trees.

\begin{tabular}{cl}
\hline Name of category & \multicolumn{1}{c}{ Description } \\
\hline 1 = very difficult & $\begin{array}{l}\text { Almost impossible to observe and measure, even with } \\
\text { permission; or no path (even without touristic signs) leading to } \\
\text { the tree. }\end{array}$ \\
\hline $2=$ poor & $\begin{array}{l}\text { Permission needed (sometimes verbal permission is enough), } \\
\text { or dense scrub on the floor. Access needs several hours on foot. }\end{array}$ \\
\hline \multirow{2}{*}{$3=$ medium } & $\begin{array}{l}\text { Short walk to reach the tree (eg. distant corners in abandoned } \\
\text { castle parks; less than one kilometre walk from a forest dirt } \\
\text { road). No accessibility by car. }\end{array}$ \\
\hline $4=$ good & $\begin{array}{l}\text { Almost accessible by car, or standing in a less well-kept (but } \\
\text { still walkable) park. }\end{array}$ \\
\hline $5=$ excellent & $\begin{array}{l}\text { Easily accessible by car, or standing in a well-kept, visitable } \\
\text { castle park. }\end{array}$ \\
\hline
\end{tabular}

We measured altogether 2000 great trees throughout the total area of Hungary, i.e., in 19 counties, 531 settlements. The highest number of trees (316) were measured in Veszprém county, where there are several wooded pastures with monumental solitary trees. The smallest numbers were detected on the Great Hungarian Plain (Figure 1).

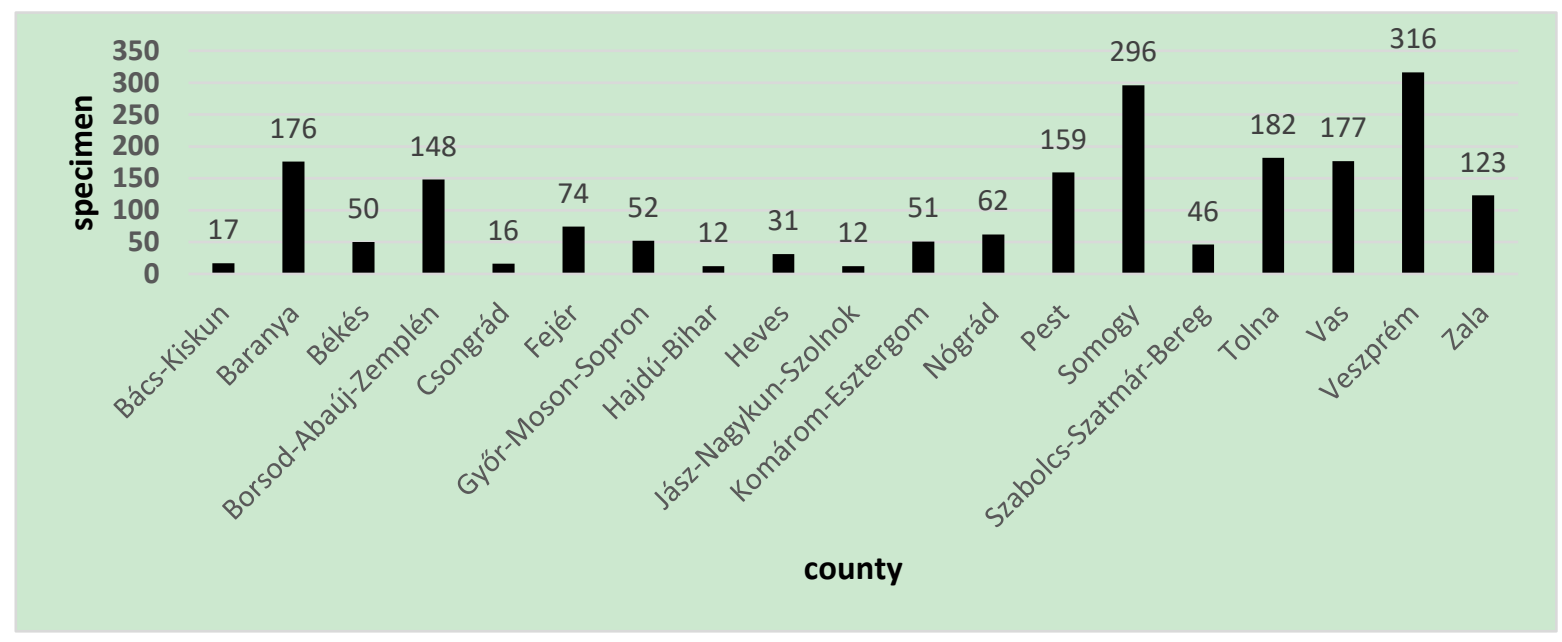

Figure 1. Number of measured trees in each Hungarian county.

\section{Results and Discussion}

The measured 2000 trees (in the area of 531 Hungarian settlements) belong to 72 species, 29 native and 43 non-native (Figure 2). 1550 specimens belong to native species, while 450 are adventive. The most frequent among the greatest tree species is beech (Fagus sylvatica; 400 specimens) and the oak genus (Quercus spp.; 427 specimens, mostly English oak, Quercus robur). The Poplar genus gives several great trees as well (Populus spp.; 226 specimens, mostly black poplar, Populus nigra). Most of them stand in a park or forest (not as a solitary tree), and live in the Northern Hungarian Mountain Range, while there is a low number of veteran trees in the Great Hungarian Plain. Currently, the greatest known tree in Hungary is a black poplar in the Gemenc forest territory with a girth of $1180 \mathrm{~cm}$. 


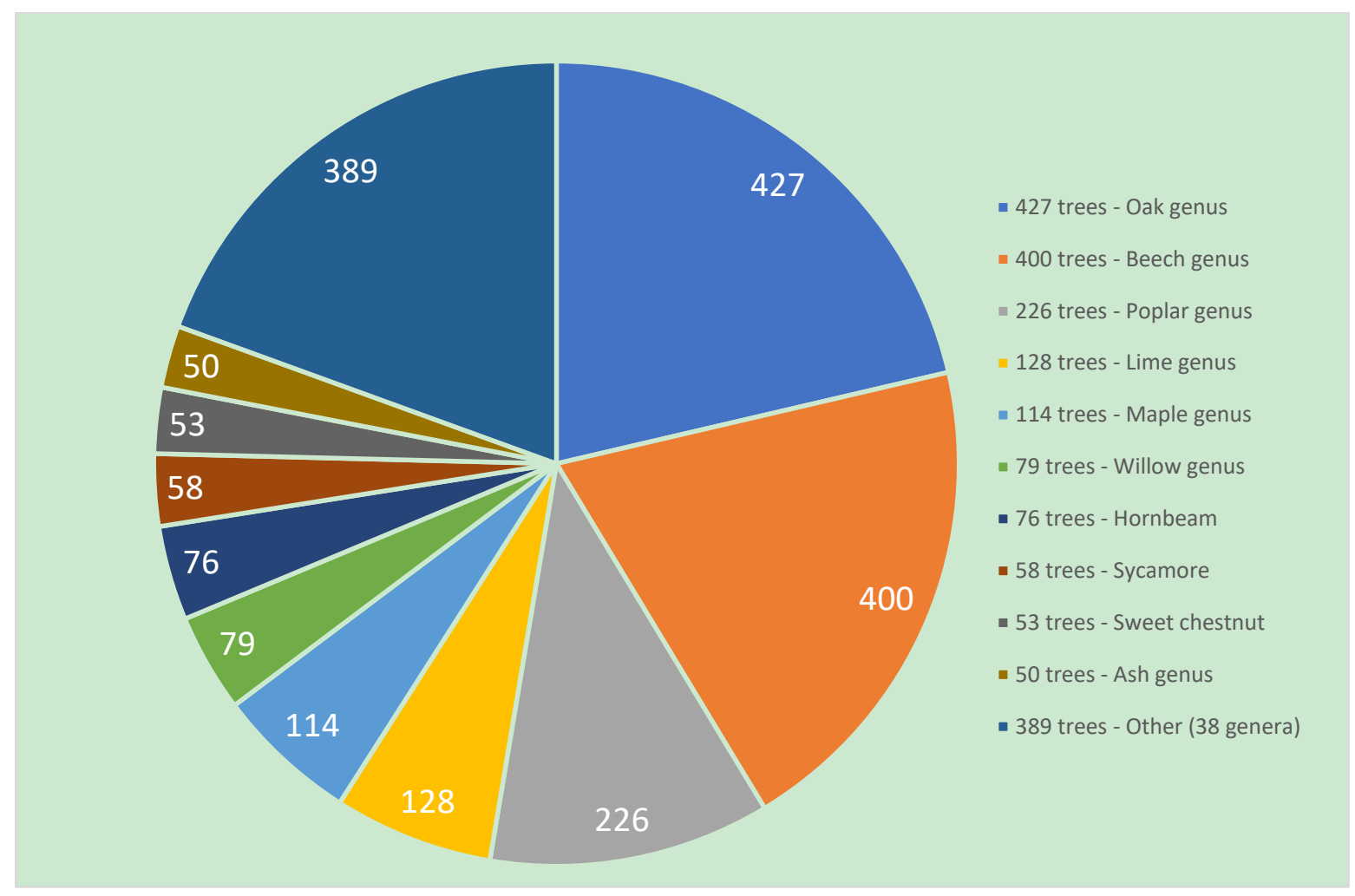

Figure 2. The measured tree species and the number of specimens within each species.

\subsection{Health Status}

In terms of health status, at least three-quarters of the measured trees are in at least fair condition (Figure 3). However, 6.05\% of the measured great trees (ie., 121 specimens) have died since their first listing in the nation-wide database or they no longer reach the size necessary to be listed (due to breakage etc.). Most of the dead trees are beech trees (Fagus sylvatica), English oaks (Quercus robur), and black poplars (Populus nigra), not surprisingly, since these are the most numerous species among the great trees. 96 out of the 121 dead trees stood in a forest or a park, while only 25 were solitary trees.

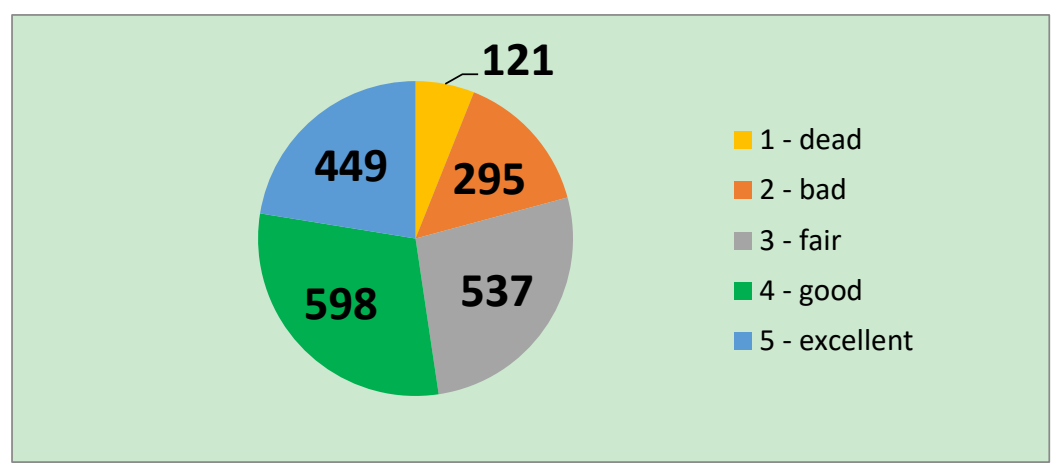

Figure 3. Health status of the measured trees.

Altogether 832 trees were found in bad or fair condition, i.e., 41.6\%. 135 of them were solitary, while 697 were in a stand (forest or park). Most of them were oaks (211 specimens) and beech (155), these are the closest to die. High numbers were detected in the case of the black poplar (81 trees), white willow (66), and hornbeam (42).

More than half of the measured great trees are in good or excellent condition (1047 specimens), 888 in forests or parks, while 159 solitary, mostly beeches (196 trees) and English oaks (150). It is important to emphasize that $94.8 \%$ of the sycamores (Platanus spp., 55 
specimens out of 58) belong to the best two condition groups. However, only $10.5 \%$ of the great black locusts (Robinia pseudoacacia, 2 out of 19), 16.7\% of the great white mulberries (Morus alba, 2 out of 12), and 10.3\% of the great white willows (8 out of 78) are at least in good condition. In the case of the great sweet chestnut trees, this ratio is $24.5 \%$ (13 trees out of 53).

\subsection{Accessibility}

Only $1 \%$ of the measured trees (i.e., 20 specimens) belonged to the $1=$ very difficult accessibility category. There is no path leading to these trees, and are several kilometres far from any road that could be accessed by car. Some of them cannot be visited even with permission (e.g., within military areas).

$7.55 \%$ of the measured trees (i.e., 151 specimens) are poorly accessible. They can be reached only on foot (but in better path conditions) or by bicycle (e.g., the giant poplars of the Gemenc forest territory). Some of them can be visited with verbal permission or after an easy administration.

The medium (3) category counts 633 trees, i.e., 31.65\%. Their vicinity (within a walking distance) can be reached by car, eg. the monumental solitary trees of the Olaszfalu wooded pasture. Several of them are hidden in distant corners of abandoned, shrubby castle parks, rarely visited and less well-kept parts of arboretums. Although no permission is needed to visit them, officially it is not allowed to leave the designated path in the latter areas and thus, these trees should be considered as unattainable (e.g., castle park of Körmend).

Good accessibility is a feature of 475 great trees, i.e., $23.75 \%$. They are almost accessible by car (e.g., until a distance on a dirt road), or standing in a less well-kept, but still walkable castle park (several examples in Borsod-Abaúj-Zemplén county). Those wooded pastures that are still in use (i.e., grazed by livestock) also belong to this category (e.g., Túristvándi).

Finally, 36.05\% of the great trees (721 specimens) stand in a well-kept park that is easy to access by car and the visitors can walk everywhere (eg., giant sycamores of the Margaret island, Budapest; or the National Botanical Garden, Vácrátót), and those that stand only a couple of meters far from the paved road. The ratios are shown in Figure 4.

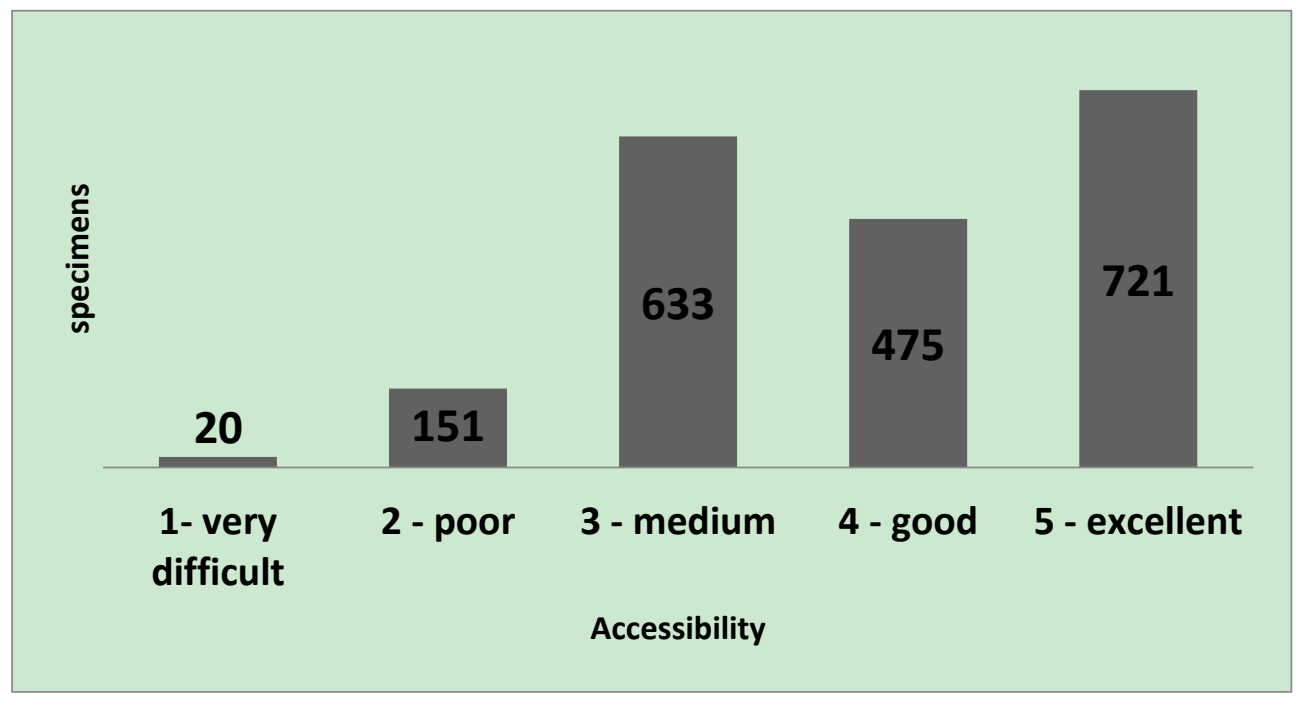

Figure 4. Accessibility of the measured great trees.

\section{Conclusions}

From the registration in the nation-wide online database until our measurement (i.e., between 2000 and 2018) 121 great trees died, mostly due to natural causes (dehydration, storm damage). This number proves that any kind of documentation is important. Only a 
bit more than half of the measured great trees are in good or excellent condition. This calls attention to their proper treatment before it is too late.

More than half of the trees are easily accessible, while only about $9 \%$ is very difficult to reach. 1745 out of the measured 2000 trees can be freely visited (i.e., without any special permission or entrance fee). Access is really hard only in the case of 171 great trees. This might be considered beneficial for the tree as well, in order to protect it from disturbances emerging from mass visiting (e.g., climbing onto the big branches).

There is only a very limited number of cases when a great tree receives legal protection even on its own (solitary tree as a local natural monument-IUCN III category), or the habitat where it stands (e.g., locally protected castle park or tree line-IUCN III category; forested area in national park or landscape protection area-IUCN IV category).

Acknowledgments: We are grateful for all the verbal information provided by György Pósfai, founder of the database on the greatest trees of Hungary and the numerous majors, nature conservation guards, as well as the local people for their stories, attached to each ancient tree.

\author{
Institutional Review Board Statement: \\ Informed Consent Statement: \\ Data Availability Statement: \\ Conflicts of Interest: The authors declare no conflict of interest.
}

\title{
References
}

1. Bergman, K.O.; Jansson, N.; Claesson, K.; Palmer, M.W.; Milberg, P. How much and at what scale? Multiscale analyses as decision support for conservation of saproxylic oak beetles. For. Ecol. Manag. 2012, 265, 133-141, doi:10.1016/j.foreco.2011.10.030.

2. Gibbons, P.; Lindenmayer, D.B.; Fischer, J.; Manning, A.D.; Weinberg, A.; Seddon, J.; Ryan, P.; Barrett, G. The future of scattered trees in agricultural landscapes. Conserv. Biol. 2008, 22, 1309-1319, doi:10.1111/j.1523-1739.2008.00997.x.

3. Lindenmayer, D.B.; Laurance, W.F.; Franklin, J.F.; Likens, G.E.; Banks, S.C.; Blanchard, W.; Gibbons, P.; Ikin, K.; Blair, D.; McBurney, L.; Manning, A.D.; Stein, J.A.R. New policies for old trees: Averting a global crisis in a keystone ecological structure. Conserv. Letters 2014, 7, 61-69, doi:10.1111/conl.12013.

4. Eriksson, O. What is biological cultural heritage and why should we care about it? An example from Swedish rural landscapes and forests. Nature Conserv. 2018, 28, 1-32, doi:10.3897/natureconservation.28.25067.

5. Takács, M.; Mravcsik, Z.; Malatinszky, Á. The greatest trees of Fejér County, Hungary. Természetvédelmi Közlem. 2015, 21, 330339.

6. Takács, M.; Mravcsik, Z.; Malatinszky, Á. Legendary lime trees of the Carpathian Basin. Ann. Faculty Eng. Hunedoara Int. J. Eng. 2015, 13, 29-32.

7. Kruse, A.; Centeri, C.; Renes, H.; Roth, M.; Printsmann, A.; Palang, H.; Benito, J.L.; Velarde, M.D.; Kruckenkberg, H. Glossary on agricultural landscapes J. Landsc. Ecol. 2010, 8, 99-127.

8. Takács, M.; Szénási, Á.; Malatinszky, Á. Polypores, Agrobacterium and ivy damage on Hungarian ancient trees. Nat. Conserv. 2020, 40, 1-38, doi:10.3897/natureconservation.40.51633.

9. Rapaics, R. Öreg fák, ősi legendák. Természettudományi Közlöny 1929, 61, 721-735.

10. Tardy, J. Magyarországi Települések Védett Természeti Értékei; Mezőgazda Kiadó: Budapest, Hungary, 1996; pp. 1-665.

11. Thickest trees of Hungary. Available online: http://www.dendromania.hu (accessed online 23 February 2021).

12. Monumental Trees. Available online: http://monumentaltrees.com (accessed online 10 September 2019).

13. Hungarian Monumental Trees. Available online: http://oregfak.emk.nyme.hu (accessed online 11 October 2019).

14. Szakonyi, Z. An overview on the cult of oak genus and presentation of some remarkable Hungarian oak trees. J. Landsc. Ecol. 2018, 16, 35-43.

15. Takács, M.; Malatinszky, Á. Overview of the European lime tree cult and the greatest lime trees of the Hungarian Transdanubia. J. Landsc. Ecol. 2009, 7, 457-464.

16. Takács, M.; Malatinszky, Á. An overview on the cult of sweet chestnut and presentation of the greatest Hungarian sweet chestnut trees. J. Landsc. Ecol. 2012, 10, 457-466. 